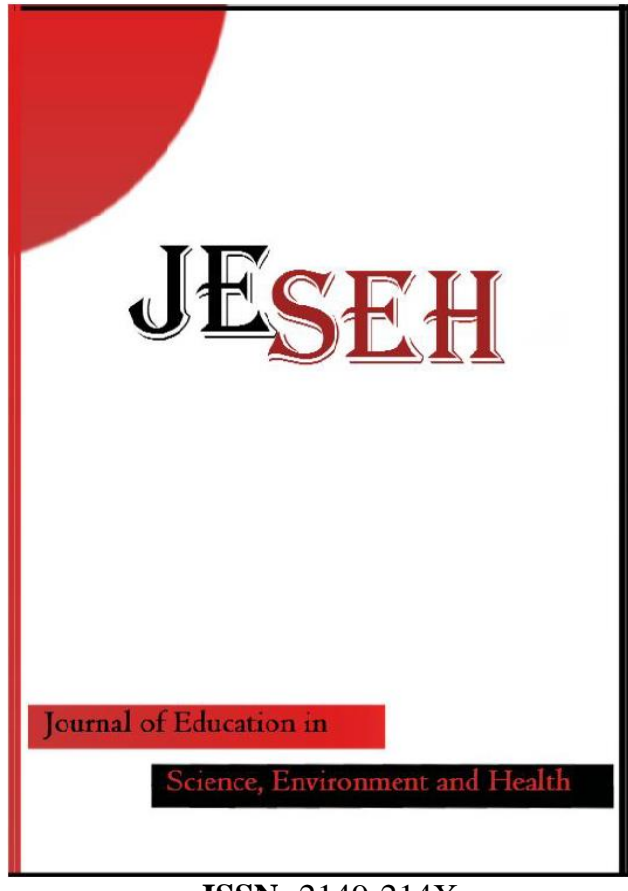

ISSN: $2149-214 \mathrm{X}$

\section{Journal of Education in Science, Environment and Health}

www.jeseh.net

Environmental Education and Perception about the Environment by High School Students and Teachers

Vinicius Ferreira Pinto, Maria Eugênia Ferreira Totti Universidade Estadual do Norte Fluminense Darcy Ribeiro

To cite this article:

Pinto, V.F. \& Totti, M.E.F. (2020). Environmental education and perception about the environment by high school students and teachers. Journal of Education in Science, Environment and Health (JESEH), 6(3), 169-176. DOI:10.21891/jeseh.705437

This article may be used for research, teaching, and private study purposes.

Any substantial or systematic reproduction, redistribution, reselling, loan, sub-licensing, systematic supply, or distribution in any form to anyone is expressly forbidden.

Authors alone are responsible for the contents of their articles. The journal owns the copyright of the articles.

The publisher shall not be liable for any loss, actions, claims, proceedings, demand, or costs or damages whatsoever or howsoever caused arising directly or indirectly in connection with or arising out of the use of the research material. 


\title{
Environmental Education and Perception about the Environment by High School Students and Teachers
}

\author{
Vinicius Ferreira Pinto, Maria Eugênia Ferreira Totti
}

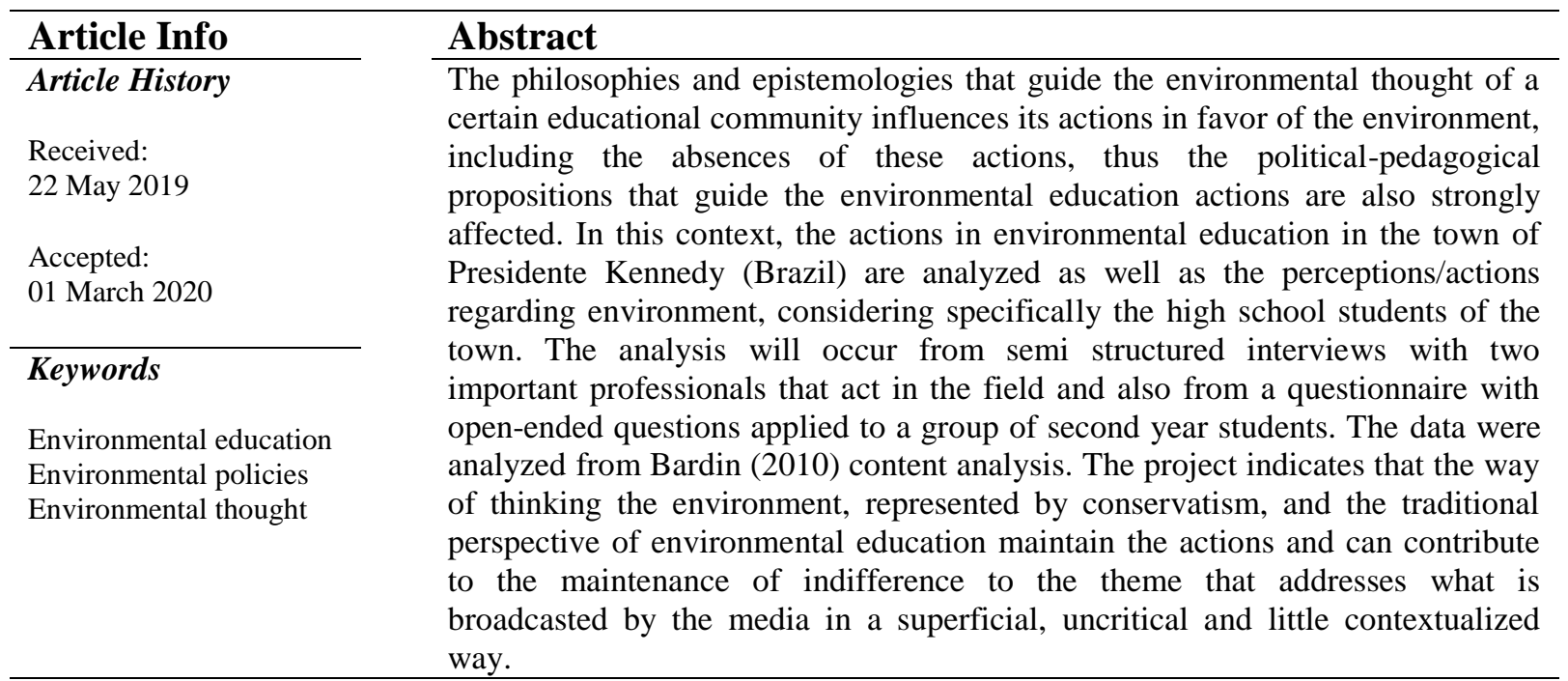

\section{Introduction}

The main restlessness is regarding men's relation with nature and has its origin bounded by modern ideas of absolute domination of nature by men, this restlessness is not restrict in biophysical or territorial aspects of the biological systems, it's included here a degeneration of men and their ethical, philosophical, cultural, aesthetic aspects (Barcelos, 1988). The men/nature dichotomy emerged with greater prominence in the scientific revolution, being enhanced in the industrial revolution in which a nature utilitarian version stands out, these perspectives were and are still supported as an important view point in society (Naves \& Bernandes, 2014). The evidences that can be understood with the change in the manner of thinking and being in the environment are in the main conditions that impregnate the human life in current times that originate from the technological advances and the more we approximate to this, the more we distance ourselves from ourselves or from our environment, it's in this sense that we can perceive the importance of education for a change in the worrisome scenario (Almeida \& Kautzmann, 2011).

It is not intended with the written above to praise the good relationship between society and nature in the periods before the pre-industrial revolution, an important mark of anthropology as described by Faldore and Taks (2004), although having acknowledged the possible impacts of the changes in the way or in proportion of usage of natural resources in posterior societies. The importance of the environment inserts in the debates in the most diverse forms of thought, the Cartesian and disciplinary scientism isn't enough to meet the demands of the environmental problems that countless times receive influence of the looks of the diverse disciplines. Morin (1991, apud Barros, 2013) argues that the understanding of ecology by society will require innumerable competences, which goes against the hyper-specialization, typical of the philosophy of modern science. The debates and actions of society in the environmental field occur within conflicts and disputes between the different entities (state, NGOs, parties, academia, among others) (Barros, 2013). The author is also aware that, however diffuse the rise of environmental debates and conflicts may be, there is a tendency to increase the structuring and centralization of power of these actors, but the interdisciplinarity and complex nature of environmental thinking is evident.

The educational paradigms that guide environmental education are strongly influenced by the way the world and the environment are perceived (Guimarães, 2004), as well as environmental policies and environmental education policies themselves. However, it cannot be stated categorically that this is a unilateral aspect, especially when we consider the complexity of environmentalism, in this sense it is recognized that 
environmental education can interfere in the way a community can perceive the environment. Understanding the thoughts that influence practices and possibly educational policies for the environment and environmental education in general, both in the formal and informal fields of the educational process, allows us to rethink our actions in this important area and may even affect our action in the world. Hence, the present work intends to reflect on the actions in environmental education and how these activities impact the view of high school students about the environment in the municipality of Presidente Kennedy, returning to the discussions for the Public Policies that seek to promote Environmental Education in the town.

\section{Method}

\section{Sample and Date Collection}

The research is characterized as qualitative, exploratorily. In the Escola Estadual de Ensino Fundamental e Médio Presidente Kennedy (EEEFM Presidente Kennedy), located in the town of Presidente Kennedy, south coast of the state of Espírito Santo, Brazil, in the only high school of the town, during the research it also included final grades of middle school and Educação de Jovens e Adultos (EJA, a modality of school for adults). According to the Brazilian Institute of Geography and Statistic (IBGE,2019) the municipality had an estimated population of 11.488 inhabitants in 2018, however, according to the TSE (Supreme Electoral Court), the municipality had 12.958 voters in February 2018, the number reduced to 10.482 in the following month, this data already shows the possibility of political and electoral conflicts in the region, this information should be considered when analyzing the socioeconomic and environmental aspects that find in the ballot box an important field of conflict.

IBGE (accessed on 24/01/2019) still states that GDP per capita, at current prices in 2018, was almost three times higher than the state capital's (Vitória), although the IDHM (Municipal Human Development Index) of 2010 was 0.657, while the capital's was 0.845. The 2015 IDEB (Basic Education Development Index) of the municipal network was 6.4 in the initial grades; surpassing the goal postulated by the Ministry of Education, however in the final series it was only 3.4. In the state network, the municipality did not present SDI in 2015 for the initial grades, only for the final grades, which the grade is 2.6, while in the ENEM (National High School Examination) of the same year it presents a mean of 447.1 (INEP, 2017).

The choice of the school in question was due to its representativeness since it comprises the only high school in the municipality. The classes that participated in the activity were selected for the adequacy of the content to the curriculum of the institution according to suggestion and guidance of the technical staff of the school. Initially, semi-structured interviews with local environmental education agents were carried out in order to create a scenario about environmental education in the municipality. The first interview was with a professional of the EEEFM Presidente Kennedy technical team, followed by a teacher of Sciences that was also numerous times in administrative activity in the municipal secretariats (of education and environment). The choice of such professionals occurred at the suggestion of the innumerable actors of education in the school and in the municipality, for recognizing the relation of their professional trajectory with the research questions. The practices in environmental education in the context of formal education in Presidente Kennedy were analyzed from semi-structured interviews conducted with the aforementioned educational professionals, one linked to the Escola Estadual de Ensino Fundamental e Médio Presidente Kennedy (EEEFM President Kennedy), and another connected also to the municipal network, both with more than a decade of professional activity in their respective jobs.

The second year high school students from that school answered a questionnaire that sought to reflect on the main themes approached in the interviews with the environmental education agents of the municipality. The questions focused on the relationship between society and the environment, on the meaning of the environment, and in the reflections and perceptions on local environmental problems. Thirty eight students participated in the research; the choice of the group of students was made by the relationship of the theme with the curriculum of students.

An interview was recorded in audio and transcribed with the appropriate authorization of the interviewee; the other was carried out by e-mail, as requested by the other interviewee. In view of the small number of professionals in the area, which would make it easier to identify, and due to the history of serious electoral conflicts in the municipality, we must faithfully respond to the request of the professionals, describing only what is necessary about their profile, so that they will be here treated by professional A and professional B, even with 
variation of the gender to which they will be treated, in this way, either professional A will be treated by the male gender, and occasionally by the female gender, the same will be done with the professional B.

\section{Data Analysis}

The interviews carried out had the objective of describing the general situation of environmental education in the town, and also to support subsequent discussions and corroborate, or not, with possible perceptions regarding the speeches of the students of the institution second year of high school, available from the data of an applied questionnaire that were treated by the content analysis in Bardin (2011).

\section{Results and Discussion}

The interviewee A affirms that there isn't a specific treatment for the environmental education in the P.P.P. (Political Pedagogical Project) of the institution or in the curriculum planning, also adding that the inclusion of the topic in the curriculum is unnoticeable. According to the professional, the environmental theme occurs according to demand, as exemplified:

For example, when we had gone through a great drought period, "right?" The water presentation topic was looked upon, as in the waste of it, and how we could avoid, but as I said, only when there's a demand (Professional A).

The approaches in environmental education are linked to demands, in general, to what is evident at a given time, which can be observed countless times in the interview. The project themes cited were: selective collection, waste of water, ecological tracks, tree planting. According to the interviewee, there is little talk or there is not talk about the local ecosystem, such as sandy coastal plains (restinga), or even about social and environmental issues.

In the previous speech, one can perceive specificity in affirming the "waste that one has to avoid" that can serve as an alert for the way in which the water issue is addressed in environmental education. Besides being a constant target of media actions, the issue of wasteful domestic water use is not the only issue about the hydric crisis (Karatas \& Karatas, 2016), which may reveal the superficiality with which the theme is treated, carrying the characteristics of conservative environmental education, since when the issue of water as a whole, its use and accessibility, and another dimension are not addressed, the socio-environmental discussions are left in the background.

The influence of mass media approached on environmental issues can be seen as a tool for propagating environmental thinking with a focus on environmental preservation and well-being, but also as a tool for the spread of interests of hegemonic groups that can be disseminated and emphasized. In this sense, Núñez and Moreno (2016) point to the importance and duality in the relationship between mass media and environmental thinking with a focus on preservation, paying attention to the need to reflect on the role of mass media that can be a powerful instrument of environmental education.

The fact that environmental approaches follow the demands demonstrates a certain distance between who designs and who executes the projects; distancing themselves from the reality of the actors involved, and, in reproducing what is in evidence, ends up responding to the logic of dominant interests, characteristic of the traditional perspective of environmental education (Guimarães, 2004). This distance and the pragmatic characteristic of the approaches evidence the reductionism of the paradigm, as well as characteristics of technicism conceptions, when emphasizing the individual changes (Layrargues, 2002).

In the town the environmental education proposals mainly derive from the City Secretary of Environment. The state school usually receives invitation to participate, and participates whenever possible, but, beside the projects not being too common, they occur according to demand as stated in the interview. The participation of the mentioned school has as limitation the curriculum and the calendar, as professional A highlights, so that it participates when possible - it is emphasized that the professional affirms not to remember any environmental education project in the state school, only some individual approaches of teachers, nothing articulated. He also reminds us that the theme of the Environment is present in the curricular proposals of the State Department of Education and in the federal proposals, but it still occurs in a simple manner in the school. 
Professional A is unaware of the projects aimed for the community with the participation of the school. He points out that environmental education, when worked on, is centered on the actions of science and biology teachers, which is also observed by McDonald and Dominguez (2010), and yet reports that if there is a need for a multidisciplinary approach, the technical team must constantly demand from teachers:

If we don't stat there, demanding, right? they procrastinate. We say that we will do it, and we'll do it, and don't do it. (...). The teachers can't perceive that it's a general problem, (...), Therefore they are not able to work together, they separate it by area (...) (professional A).

Professional A, when talking about interdisciplinarity, mentions the work of numerous disciplines on a theme, an approach in fact of multidisciplinary origin, because according to Pires (1998), within the context of teaching, this perspective seeks to treat the same theme in the different disciplines, each one within its strategies and its focuses, different from the interdisciplinary approach that goes beyond the sharing of information, techniques and bibliographies, is proposed in an epistemological reconstruction.

This difficulty in promoting an interdisciplinary approach demonstrates another obstacle to the insertion of environmental education in a critical perspective in the school, corroborating with the Cartesian-mechanistic paradigms typical of a traditional environmental education that ignores the notion of environmental complexity (Guimarães, 2004). A relevant fact described highlighted by professional A is that municipal environmental education projects occur preferably in the three daycare centers of the town and in the four poles schools, those with the largest number of students, even the municipal network having approximately 20 schools, this fact allows questioning the effective objectives of projects in environmental education, especially with regard to the objective of addressing environmental issues and not just to respond to legislation. At the end of the interview, professional A said he believed in the need to approach the subject and that this approach should be worked beyond the walls of the school, starting from generating themes. The perspective followed by the interviewee meets what Caillon et al. (2017), when proposing the need to break the dichotomy between nature and culture, as well as reinforcing the idea that men is part of nature which could influence conservation practices.

Professional B affirms that projects in environmental education emanate, in general, from the Municipal Department of Environment, which develops them in partnership with the Municipal Department of Education, which usually adopts state and federal government projects. According to the interviewee, there is little agreement with the private sector, he said that, in view of the implementation of the port complex of Porto Central, the Municipal Master Plan (PDM), which is still under discussion and undergoing modifications, proposes, in Article 163, ecology as a common discipline in the municipal network.

When asked about the philosophical and theoretical approaches of environmental education projects, the interviewee (professional B) quotes Izabel Carvalho, a researcher who works on environmental education in Brazil, also cited the legislation in force, without necessarily referencing, describing the main ideas or the perception of the author and legislation on the subject. Professional A, claims to believe in the need to work on environmental education in a preventive perspective, in order to avoid environmental problems, without necessarily presenting any basis or reference.

The treatment given by both interviewees to the theoretical and philosophical discussions inherent in environmental issues corroborates with the characteristics of the thought that deals with environmental education in a preventive perspective, because according to the interviewee A it should be practiced in order to avoid environmental problems of seeking the support of results that are still to come, avoiding theoretical and philosophical deepening, which hinders the planning of possible actions and decision-making on broader and more comprehensive issues. The preventive perspective shows that the objective of projects in environmental education are aimed by those who project them, focused on the interests of hegemonic groups, pragmatic projects with the purpose of modifying individual behavior, that would occur to avoid problems, showing that critical debates and complex projects inserted in socio-environmental issues and with a prospect of changing socio-environmental reality are seconded.

In proposing typologies for environmental education, Silva and Campina (2011) present three proposals: traditional and critical, as well as Guimarães (2004), and add the pragmatics, which according to the authors "presents a focus on action, in search of solutions for the environmental problems and the proposal of norms to be followed "(Silva \& Campina, 2011). This perspective of environmental education contrasts with criticism because it fails to emphasize the complexity of the human-nature relationship, the political dimension and the questioning of the current productive and economic model. 
The pragmatic perspective of environmental education seems to fit into the activities described by the interviewees, because they assume the need for individual change, focusing on practical activities designed and idealized by others, such as ecological walk and separation of waste in selective collection, activities in environmental education that were most cited.

Environmental education in the town of Presidente Kennedy is far from the critical perspective, starting from the analysis of the data obtained in the interviews, especially when it is not observed to seek to transform the reality of the students and the community. The legislation assists in order to impose a minimum of involvement and relationship between the government and the community in the ambit of the environment, however, actions occur unilaterally, without the quest to awaken in citizens the need to get involved with environmental issues, hindering the sense of belonging and participation, which is sometimes confined to associations that end up seeking only economic improvements, as the interviewees report.

The students participating in the research answered a questionnaire with open questions that addressed their respective perceptions about the socioenvironment. The responses were treated by the content analysis in Bardin (2011) as described in the method. The issues specifically addressed: i. The relationship between society and the environment, ii. The meaning of the environment, iii. Identification of environmental problems, iv. Resolution of environmental conflicts. The figure 1 presents the categories and frequencies of the answers regarding the students' understanding of the relation between environment and society.

Table 1. Frequency of the answer categories of the students about the questioning of the relations between the society and the environment.

\begin{tabular}{lc}
\hline \multicolumn{2}{c}{ Frequency } \\
\hline The society depends on nature (focus on economical & 4 \\
development). & 6 \\
Dificulty in collective thinking (focus on individual actions). & 12 \\
Constant harmful relationship to the environment & 1 \\
Necessity of research and studies. & 7 \\
Didn't answer.
\end{tabular}

The idea that the relationship between society and nature has always been harmful to the environment, representing the idea of the need to promote environmental conservation without human presence, presents a tendency towards conservative perspectives of the environment. Loureiro (2004) presents the environmental conservation paradigm that, among others, has the characteristics of biodiversity preservation and intact areas, thus establishing a dissociation between men and nature. The association between the conservationist idea of nature, described in the previous paragraph, added the idea that society depends fundamentally on access to natural resources. For example, as seen in the category "society depends on nature"; exposes the mercantilist and exploratory view of the world. Leff (2006) demonstrates the relationship between the conservation paradigm and the capitalization of the environment:

[...] the nature ceases to be an object of te work process to be codificated in terms of capital. But this relationship does not return the being to the nature, but it transmutes in a form of capital - natural capital -, generalizing and amplifying the forms of economical value of nature. In this sense, along with the forms of intensive exploration, it promotes in a "conservationist" of nature. The biodiversity appears not only as a multiple forms of life, but as "natural reserves"- territories and biological diversity and cultural habitats - that are being valued for its genetic wealth, its ecotourism resources and its functions as carbon collectors" (Leff, 2006, pg. 146).

Table 2. Frequency of the answer categories of the students about the meaning of environment.

\begin{tabular}{lc}
\hline Answer categories & Frequency \\
\hline Importance of the environment for mankind & 9 \\
Nature (biological and/or biophisical, without human & 7 \\
insersion). & \\
Environment (Society, men/environment, etc.). & 5 \\
Natural beauty, tranquility, etc. & 3 \\
Life. & 2 \\
Unanswerd. & 7 \\
\hline
\end{tabular}

The perception regarding the relationship between the environment and society of students go through the meaning of environment for them, in this sense, the figure 2 presents the categories of the answers and its 
frequencies. The category natural beauties, etc. can represent to some extent the students' romantic perception about the environment. In this category, answers are classified as;

a quiet place where we can live (student A),

or even

life, clean air, health... (student B).

Considering that the concept of nature is essentially political and historical, the romantic vision of the environment that exalts nature and its wonders, can also be perceived as a utilitarian perspective that sees the environment as an instrument or space used for leisure and relaxation (Tamaio, 2002). When seeking to describe environmental problems experienced by the family members or the students themselves, the answers were categorized and the frequency is presented in figure 3.

Table 3. Frequencies of the experiences with environmental problems that the student has faced.

\begin{tabular}{lcc}
\hline Answers & Frequency & $\begin{array}{c}\text { Percentage } \\
(\%)\end{array}$ \\
\hline Water supplying, droughts, floods in the city & 4 & 14 \\
Deforestation in the city & 7 & 23 \\
Out of town topics or without specific & 10 & 33 \\
location (garbage on the streets, global & & \\
warming, etc.) & 9 & 30 \\
Unanswered & 30 & 100 \\
Total & & \\
\hline
\end{tabular}

The question of water resources presented by the students is directly related to the daily life of the Kentish community, which can be observed in the speech of the professional A when interviewed, as well as the issue of deforestation that sometimes appears implied in the speeches. However, important data refers to the high number of approaches to problems outside the community of these students, major environmental disasters that have won the media, such as the pollution of the Tietê River (SP), the rupture of the dam in Mariana City (MG), among others. The observation also corroborates with the speech of the Professional A who points out the media as the main provider of themes for the work on environmental education in the school. In this sense, students were asked about the ways to resolve possible conflicts arising from environmental disputes, The figure 4 shows the frequency of categories.

Table 4. Answers about the forms of resolution to environmental issues

\begin{tabular}{lc}
\hline Answers & Frequency \\
\hline Individual actions, ex.: (each doing their own part) & 6 \\
"Avoid being selfish" & 5 \\
Council meetings, dialogues, respecting opinion, etc. & 3 \\
Without answer or lacking examples of conflicts & 11 \\
Population awareness & 5 \\
Studies and researches about the environment & 1 \\
Rules, laws, etc. & 1 \\
\hline
\end{tabular}

Non-individualized approaches were mentioned only 8 times (category that addressed council meetings and awareness), affirming dialogue and awareness, and the resolution of conflicts that was presented by most responses highlights an individualistic perspective, where self and other have difficulties in coexisting, further deepening the dissociation between men and nature and men to men, making it difficult to act in favor of the environment, since for most of the students the other is the egoistic, which damages the environment, etc. In summary, the environmental perspectives pointed out in the students' discourses are consistent with the practices of the Policies and with the vision of environment and environmental education that prevails in the town. At this point, one can direct thought to a political-philosophical system fed by traditional environmental education, which in turn feeds the political-philosophical system in question, as in a vicious cycle at the local level that needs to be broken.

However, it is also known that the school paradigm, alien to society, is no longer viable in the face of social changes, especially with the new technologies of learning and communication (Baladeli et al. 2012), so it would 
be naive to expect that what would be a cycle indefinite duration, or that it actually constitutes a cycle. In treating the relationship between the praxis of public policies in environmental education and the perception of the environment of the students in this research, we open the way to the recognition of the complexity and importance of the topic for the maintenance of human life on earth, making it necessary, in this sense, (re) thinking about the discourse of financial systems regarding the role of the State and consequently its size.

The neoliberal perspectives in which financial systems are immersed recognize and implore a minimal state, however we must turn our attention to the direction of this minimum state. For Loureiro and Ribeiro (2010), the minimum state in the neoliberal perspective turns to its public character, while for its character of maintainer and guarantor of the capital expansion, a maximum state must be assumed (Netto, 2012), acting on incentives, financial aid, credit programs, etc. In this sense, the role of the State on the environmental issue, especially in its exploration and degradation must be at the service of society and not the financial system, since it comprises fundamental aspects for the maintenance of life on Earth. ORyan and Ibarra (2016) state that in the 2000s, changes in Latin America's perceptions of the environment also stimulated changes in environmental policies, including greater state intervention in the activities of companies that may harm the environment. However, the regulatory mechanisms need always be reviewed, that the polluting agents not may seek loopholes or even compensations that may circumvent such mechanisms, once again the promot environmental education can stimulates thinking and feeling about environment, local or not, it emerges as an important tool for promoting and maintaining the development of practices that seek environmental preservation.

Although we can consider a myth as the idea that education should save humanity, we can not deny what Freire (2001) affirms: "not being able to do all, the educational practice can do something" (p. 47), in this sense, we need to highlight that although public policies in environmental education can not be immersed in a naive optimism, we need, above all, to recognize their role in the face of public and popular education practices, since it is within the individual existence inserted in a collective society that promotes environmental awareness. Schild (2016) in discussing environmental citizenship reminds us of Tbilisi's 1977 declaration, recognizing environmental citizenship as fundamental to the transition to sustainability, also raising discussions on the important notion that environmental citizenship sought in education, is directed beyond specific knowledge and mental habits, it is necessarily oriented towards practice, behavior and attitudes in which the individual is (re) constructively collective.

(...) The role of the environmental education in this project is to be able to offer students the opportunity to learn as active citizens within their communities through the participation and civic engagement, and at the same time, helping students to understand the root structures and systematics of the social and environmental problems (Schild, 2016, p. 31).

The author also cites the relevance of local environments in environmental education that seeks the development of literacy / environmental literacy and, above all, for the much-desired environmental citizenship. In this sense, Leme, Noronha and Viana (2009) leads us to reflect on an important tool that is the youth protagonism applied to environmental education showing us the importance of considering and exploring the characteristics of different stages of human development for practices, especially referring to environmental education in formal teaching environments.

\section{Final Considerations}

Environmental education in the town of Presidente Kennedy-ES is shown to be inserted in the context of traditional environmental education, as well as in the significant distance between the Policies focused on environmental education and local socio-environmental reality. The rise of large port commerce is a significant argument for greater attention to environmental aspects, which also include environmental education, to include the community in the debates on existing environmental conflicts and, above all, those that are yet to come. so that lives are not subjugated to economic dependence. The close relationship between environmental education policies and the perception of the participating students shown in this research demonstrates the need for greater participation of the various sectors of society as a community association, NGOs, environmentalists, education professionals, among others, in debates about the challenges of the future. Finally, it is emphasized here that the school can be the locus of discussions about the environment, especially in places with the characteristics described here, since there are those who need each time more to be aware of aspects regarding youth protagonism. The approximation between school and society can be a factor for strengthening the discourses of different citizens, the approach of men / nature, and the struggle for a future different from that projected to the planet. 


\section{References}

Almeida, J. C. T. \& Kautzmann, R. M. (2011). A filosofia da natureza e educação ambiental: uma reflexão crítica na busca de uma direção ética. La Salle - Revista de Educação, Ciência e Cultura, 6, 43-56.

Baladeli, A. P. D., Barros, M. S. F. \& Altoe, A. (2012). Desafios para o professor na sociedade da informação. Educar em Revista, 45, 155-165.

Barcelos, V. H. L. (1988). Tendências da Educação Ambiental Brasileira. Santa Cruz do Sul: EDUNISC.

Bardin, L. (2011). Análise de conteúdo. São Paulo: Edições 70.

Barros, A. T. (2013). O ambientalismo como interdisciplinar sociocultural e pensamento complexo. Perspectivas, 44, 63-91.

Caillon, S., Cullman, G., Verschuuren, B. \& Sterling, E. (2017). Moving beyond the human-nature dichotomy through biocultural approaches: including ecological well-being in resilience indicators. Ecology and Society, 22(4).

Foladori, G. \& Taks, J. (2004). Um olhar antropológico sobre a questão ambiental. Mana, 10, 323-348.

Freire, P. (2001). Política e educação. São Paulo, Cortez.

Guimarães, M. (2004). A formação de educadores ambientais. Campinas-SP: Papirus.

IBGE - Instituto Brasileiro de Geografia e Estatística. (2019). https://www.ibge.gov.br/ (last checked 19 March 2019).

INEP-Instituto Nacional de Estudos e Pesquisas Educacionais Anísio Teixeira. (2019). http://www.inep.gov.br/ (last checked in 19 March 2019).

Karatas, A. \& Karatas, E. (2016). Environmental education as a solution tool for the prevention of water pollution. Journal of Survey in Fisheries Sciences, 3(1), 61-70.

Layrargues, P. P. (2002). A crise ambiental e suas implicações na educação. In: Quintas, J. S. (Eds.). Pensando e praticando a Educação Ambiental na gestão do meio ambiente. Brasília: IBAMA, 161-198.

Leff, E. (2006). Racionalidade Ambiental: a reapropriação social da natureza. Translated of Luís Carlos Cabral. Rio de Janeiro: Civilização Brasileira.

Leme, S. G., Noronha, M. G. R. C. S. \& Viana, L. H. (2009). Protagonismo juvenil e educação ambiental por meio de atividades lúdicas. IX Congresso Nacional de Educação (IX EDUCERE), Curitiba-PR: PUCPR.

Loureiro, B. R. C. \& Ribeiro, D. C. (2011). Política social neoliberal: expressão da necessária relação estado/capital em tempos de crise estrutural do capital. Mediações, 16, 292-308.

Loureiro, C. F. B. (2004). Educação ambiental transformadora. In: Layrargues, P. P. (Eds) Identidades da educação ambiental brasileira. Brasília: MMA/DEA. 65-84.

Mcdonald, J. T. \& Dominguez, L. A. (2010). Professional preparation for science teachers in environmental education. In Bodzin, B. S., Klein, \& S. Weaver (Eds.) The Inclusion of Environmental Education in Science Teacher Education. Dordrecht: Springer.

Naves, J. G. P. \& Bernardes, M. B. J. (2014). A relação histórica homem/natureza e sua importância no enfrentamento da questão ambiental. Geosul, 29, 7-26.

Netto, J. P. (2012). Crise do capital e consequências societárias. Serviço Social \& Sociedade, 111, 413-429.

Núñez, Y. C. R. \& Moreno, O. J. C. (2016). Communication and environmental conservation: advances and challenges in Latin America. Revista Latina de Comunicación Social, 71, 15 - 39.

Oryan, R. Ibarra, C. (2016). Environmental Policy in Latin America. Global Encyclopedia of Public Administration, Public Policy, and Governance, $1-9$.

Pires, M. F. C. (1998). Multidisciplinaridade, interdisciplinaridade e transdisciplinaridade no ensino. Interface Comunicação, Saúde, Educação, 2, 173-182.

Schild, R. (2016). Environmental citizenship: What can political theory contribute to environmental education practice?, The Journal of Environmental Education, 47, 19-34.

Silva, R. L. F. \& Campina, N. N. (2011). Concepções de educação ambiental na mídia e em práticas escolares: contribuição de uma tipologia. Pesquisa em Educação Ambiental, 6, 29-46.

Tamaio, I. (2002). O professor na construção do conceito de natureza: uma experiência de Educação Ambiental. São Paulo: Annablume, WWF.

\section{Author Information}

\footnotetext{
Vinicius Ferreira Pinto*

Universidade Estadual do Norte Fluminense Darcy Ribeiro

Campos dos Goytacazes-RJ, Brazil.

Contact e-mail: vinicius.uenf@gmail.com

ORCID iD: 0000-0001-9016-5279
}

Maria Eugênia Ferreira Totti

Universidade Estadual do Norte Fluminense Darcy Ribeiro

Campos dos Goytacazes-RJ, Brazil

ORCID iD: 0000-0003-4618-4522 